\title{
The search for oneself: Introductory notes on ethics and anthropology
}

\begin{tabular}{|c|c|}
\hline \multicolumn{2}{|c|}{$\begin{array}{l}\text { Author: } \\
\text { J.P. (Kobus) Labuschagne }{ }^{1}\end{array}$} \\
\hline $\begin{array}{l}\text { Affiliation: } \\
{ }^{1} \text { Department } 0 \\
\text { History and Po } \\
\text { of Pretoria, So }\end{array}$ & $\begin{array}{l}\text { fhurch } \\
\text { lity, University } \\
\text { uth Africa }\end{array}$ \\
\hline $\begin{array}{l}\text { Note: } \\
\text { This article is d } \\
\text { Prof. Dr James } \\
\text { Dr J.P. (Kobus) } \\
\text { is participating } \\
\text { fellow of Prof. } \\
\text { Duncan, Depar } \\
\text { Church History } \\
\text { Faculty of The } \\
\text { the University } \\
\text { Pretoria, South }\end{array}$ & $\begin{array}{l}\text { dedicated to } \\
\text { Alfred Loader. } \\
\text { Labuschagne } \\
\text { as research } \\
\text { Dr Graham } \\
\text { rtment of } \\
\text { and Polity, } \\
\text { ology, at } \\
\text { of Pretoria, } \\
\text { h Africa. }\end{array}$ \\
\hline $\begin{array}{l}\text { Corresponden } \\
\text { Kobus Labusch }\end{array}$ & $\begin{array}{l}\text { Ice to: } \\
\text { nagne }\end{array}$ \\
\hline $\begin{array}{l}\text { Email: } \\
\text { kobus.labusch } \\
\text { telkomsa.net }\end{array}$ & agne@ \\
\hline $\begin{array}{l}\text { Postal address } \\
\text { Private Bag X2 } \\
\text { 0028, Pretoria, }\end{array}$ & $\begin{array}{l}\text { 0, Hatfield } \\
\text { South Africa }\end{array}$ \\
\hline $\begin{array}{l}\text { Dates: } \\
\text { Received: } 12 \mathrm{~A} \\
\text { Accepted: } 30 \mathrm{n} \\
\text { Published: } 07\end{array}$ & $\begin{array}{l}\text { Apr. } 2013 \\
\text { May } 2013 \\
\text { Aug. } 2013\end{array}$ \\
\hline $\begin{array}{l}\text { How to cite th } \\
\text { Labuschagne, } \\
\text { 'The search for } \\
\text { Introductory n } \\
\text { ethics and antl } \\
\text { HTS Teologiese } \\
\text { Theological Stu } \\
\text { Art. \#1986, } 14 \\
\text { dx.doi.org/10. } \\
\text { v69i1.1986 }\end{array}$ & $\begin{array}{l}\text { is article: } \\
\text { J.P., 2013, } \\
\text { r oneself: } \\
\text { otes on } \\
\text { hropology', } \\
\text { e Studies/ } \\
\text { udies 69(1), } \\
\text { pages. http:// } \\
\text { 4102/hts. }\end{array}$ \\
\hline $\begin{array}{l}\text { Copyright: } \\
\text { (C) 2013. The A } \\
\text { Licensee: AOSI } \\
\text { OpenJournals. } \\
\text { is licensed und } \\
\text { Creative Comn } \\
\text { Attribution Lic }\end{array}$ & $\begin{array}{l}\text { uthors. } \\
\text { IS } \\
\text { This work } \\
\text { der the } \\
\text { nons } \\
\text { ense. }\end{array}$ \\
\hline 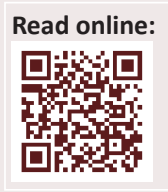 & $\begin{array}{l}\text { Scan this QR } \\
\text { code with your } \\
\text { smart phone or } \\
\text { mobile device } \\
\text { to read online. }\end{array}$ \\
\hline
\end{tabular}

Human beings make choices, and get caught up by their choices. One cannot escape the choices one has made. Your choices draw the picture of who you really are. Sometimes you are haunted by the dire consequences of the choices you have made. Where does the necessity of taking responsibility for yourself, and the choices you have made, take you? Ethics and moral conduct make sense only in conjunction with the moral agent - humankind. This article is an introductory reflection on ethics and anthropology. The argument develops mainly from the view of a human being as a relational being. People are inescapably relational beings - always being in relation with other human beings, and never able to sever the lifesaving ties to God as the human being's Maker. Human beings become themselves in relation to other human beings, and ultimately in relation to the One Other, God their Creator and Re-creator.

\section{Introduction}

There is an inscription over the gateway leading into the ancient temple of Apollo at Delphi, intended to challenge the people of ancient times, which reads: 'Know thyself' (Scott 1978:220). And the challenge still holds for today: Human beings are beings ever in search of themselves. The continuing question remains: What is man?

In touching upon the question of Immanuel Kant (1724-1804) - 'Was ist der Mensch?' - the postmodernist philosopher, Michel Foucault (1926-1984), comes to an expectantly inconclusive response:

To all those who still wish to talk about man ... to all these warped and twisted forms of reflection we can answer only with a philosophical laugh - which means, to a certain extent, a silent one. (Foucault 2002:373)

Nevertheless, Foucault refers to man's finitude and describes it as 'a finitude that is as much that of consciousness as that of the living, speaking, labouring individual' (Foucault 2002:371). And with that he contributes towards understanding the human species.

Augustine (354-430) is aware of humankind's restlessness, ever searching, and he then praises God in whom human restlessness finds its goal: 'You, for You have made man for Yourself and restless is the human heart until it comes to rest in You' (Augustine 2003:11). John Calvin (15091564 ) teaches that the knowledge of humans is connected to the knowledge of God: '[N]o man can survey himself without forthwith turning his thoughts towards the God in whom he lives and moves' (Calvin 1964:37). According to Sören Kierkegaard (1813-1855) Christianity understands humans from the mirror of God's Word - self-knowledge is not possible without knowledge of God, and without standing before God (Kierkegaard 1974:132).

Answers, at least to some extent, to the question of what humanity is comprised of, need to be found in what people experience and what their existence reveals about being a human in this world.

Humans do the things we do. We think, we feel, we do. True to our nature, all of our contemplations, emotions and deeds are related to who and what we are as being human. Being human and the deeds of humans are always connected, naturally connected. Anthropology and ethics go together; they are interrelated. Therefore, as humans we are accountable to ourselves and to the world for everything we project of ourselves. Indeed, whether ethically judged as right or wrong, our deeds are always predisposed within the parameters of being human.

This means that the questions of ethics and moral behaviour can only be approached and thoroughly considered when this is done on the basis of a profound understanding of anthropology. Ethics and moral conduct make sense only in conjunction with the moral agent - and that can only be a human being. 
This article is consequentially a reflection on ethics in its relation to anthropology.

The complexities of the subject allow only for a selection of a few introductory notes, within our limited space.

\section{Being human is to be free, and freedom demands responsibility: The propensity towards human destructiveness}

As humans we are born with the wonderful awareness of being free. To be free affords us countless opportunities and challenges to reach the heights of being human. The essence of humanity is to be free, and no one and nothing can really annihilate that. Even in captivity under the dreadful rule of tyrants, speechless and seemingly passive, the human mind is still ever free: free to think, free to feel, and free to choose. And yet, human freedom is worth not much without our giving it respectable moral substance and personal integrity. The wonderful awareness of being free is at the same time human existence facing the barely bearable 'condemned to be free' (Sartre 1977:553). In freedom of choice, which we are unable to resist or escape from, we give form to who we are. In the words of Jean-Paul Sartre (1905-1980): 'I choose myself from day to day, and I make it mine by making myself' (Sartre 1977:555). This is human existence on life's path of becoming our human selves. However, doomed to be free is necessarily also connected to doomed to be responsible. We are inescapably doomed to be responsible. In drawing moral responsibility to the fore, Sartre (1977) elaborates on the full weight of our burden:

$[M]$ an being condemned to be free carries the weight of the whole world on his shoulders; he is responsible for the world and for himself as a way of being. (p. 553)

Sartre (1977) adds:

I am responsible for everything ... Therefore everything takes place as if I were compelled to be responsible. I am abandoned in the world ... engaged in a world for which I bear the whole responsibility without being able, whatever I do, to tear myself away from this responsibility for an instant. (pp. 555, 556)

In freedom and responsibility human beings are compelled to find themselves, and to find themselves as being human. That is Sartre's thinking, also the thinking of many other philosophers. Even theologians would agree to this line of thinking, albeit not without certain theological qualifications. Ethics and anthropology are to be understood in conjunction with one another. The unpleasant question still remains, though: What if ethics should go astray and be lost? Then one would find the becoming of oneself in total chaos. This is exactly where the philosophers lack the answers and go wrong - and that is indeed too ghastly to contemplate. It is precisely here, at the most vulnerable spot of philosophical ethics and anthropology, where Karl Barth (1886-1968) brings the bad news to philosophy's captivity in human immanency.

Barth plunges us into the centre of all ethical and anthropological problems, in a severe crisis, the most severe crisis of the whole of humanity: 'When we speak of the problem of ethics today,' Barth says, 'we are faced not with $a$ problem but with the problem' (Barth 1957:142). That really means that we cannot even think of trying to begin with solving any ethical problem. No philosophy and no science can even try to begin, before we have attended to 'the problem' that Barth refers to. Barth (1957) says:

[T] he ethical problem threatens man... The era of the old ethics is gone forever. Whoever now desires certainty must first of all become uncertain. ... It is simply that over against man's confidence and belief in himself, there has been written, in huge proportions and with utmost clearness, a mene, mene, tekel.... The ethical problem is the crisis of man, the sickness of man unto death. (pp. 148, 149, 151)

In responding to the moral philosophy of Immanuel Kant, Barth (1957) says:

We know that no personality whose will is governed by the idea of humanity and is therefore a pure and autonomous and good will - we know that no such moral personality has ever stepped into our world ... There is no such thing in time or space as a human will determined by pure practical reason. (p. 154)

Barth (1957) further says:

Man's will is and remains unfree: he lives and will live to the end of his days under the annihilating effect of the fall; his conduct will be evil, and his achievement not only incomplete but perverted. (p. 70)

The heart of the problem is therefore in short: people are born sinners. And that is humanity's sickness unto death. A human being's freedom is thus confined to the parameters of being a sinner. What hope can there now be for a meaningful life and the future, if one is to be kept as a captive within the boundaries of being a lost sinner? But then God, in his unending love and grace, does not forsake humankind in their predicament. Barth finds the 'solution to the ethical problem' in 'God who becomes man', in 'the one who was crucified, dead, and buried, who descended into hell, but rose again from the dead' (Barth 1957:181, 182). In this context, ethics therefore means that a change of heart is required. It actually means a fundamental transformation, the realisation of a new humanity, in and through Jesus Christ.

Real freedom only becomes a reality in and through one's encounter with Jesus Christ, God and Saviour, and living as a new being through his Spirit. Jesus said to those who believed in him: 'If you obey my teaching, you are really my disciples; you will know the truth, and the truth will set you free' (Jn 8:31, 32).

In a postmodern world, human freedom and ethical responsibility will have to take account of the aspirations of both unity and plurality interacting with one another, and balance the freedoms and rights of both. The challenge of unity and plurality is also related to the freedoms and the rights of majorities and minorities, groups and individuals, gender and race, all people irrespective of class and position, views or knowledge. All people are important to God, and therefore ethics will have to take all people of all origins and backgrounds into account, in a well-balanced way. In 
referring to the 'deep, bitter divisions that threaten the whole future of man today along the lines that separate race from race, nation from nation, class from class', Macquarrie sets the challenge of 'the goal of unity-in-diversity and diversityin-union' (Macquarrie 1975:25, 26). The real danger lies in taking unity too far (and then suppressing diversity, in denying the particular person and group their freedom and rights, and to be themselves) - or to take diversity, the particular, too far (by making any form of collaborative effort or unity impossible in denying all non-members of a society equal freedom and rights). In referring to Romans 15:7 ('Accept one another, then, for the glory of God, as Christ has accepted you.'), Moltmann (1926-) renders an appreciable perspective on human freedom and responsibility, with the remark: 'I feel completely free where I can be completely myself' (Moltmann 1999:206, 207). He then adds, with regard to the otherness of other people: 'I shall be free when I open my life for other people and recognize them in their otherness ... Human freedom is realized through mutual recognition and acceptance' (Moltmann 1999:207). Moltmann's way is truly a fair and well-balanced Christian ethical approach. On the other hand, disappointing and unfair but nevertheless very true, is the ever-timely warning of José Ortega $Y$ Gasset (1958:60) against the crowd mentality: For the crowd mentality everything excellent, unique and different is unacceptable - 'to be different is indecent'.

What becomes clear in the reality of life, in ethical terms, is that one is constantly unmasked as a dreadful sinner when one's selfishness and greed claim freedom for oneself and control for everybody else, in order to overrun and overrule everything and everyone, shamelessly and heartlessly (cf. 10th Commandment, Ex 20:17 \& 1 Tim 6:10; cf. Labuschagne 1987:955-965). The ruthlessness of the crowd mentality also reveals this (cf. Ortega Y Gasset 1958:51-60). And it surely portrays humankind as a sociopolitical and economic monster - the moment humankind grasps power and is supported by the ruthless onslaught of the masses. History proves this reality in the many disasters and tragedies created by mass movements, such as Nazism and Communism and many others. J.E.E. Dalberg, better known as Lord Acton (1834-1902), rightly said: 'Power tends to corrupt, and absolute power corrupts absolutely' (Dalberg 1970:1). The crowd mentality has a total lack of proper moral consciousness (cf. Ortega Y Gasset 1958:267268). In the crowd and as part of the masses, people do the most brutal things, things that would otherwise never have crossed their minds, were they on their own as individuals. Group propaganda, and the interaction of the masses, can be unbelievably terrifying. Without morality, then, disaster and tragedy are bound to strike.

Wolfhart Pannenberg (1999) brings political and utopian dreams, which ultimately always seem to fail dismally, into perspective with his strong emphasis on the eschatology, and he then points out that human beings' future is essentially to be found in their relation to God, which will unfold in God's coming Kingdom and his transformation of the world:
Christian theology can also unhesitatingly appeal to the teleological meaning of the Aristotelian concept of nature, it must, however, see human beings as achieving their destiny of full 'autarky', not in the political order of the state but only in their relation to God and in the community of God's kingdom. (pp. 449, 450)

In elaborating on power and rule, Pannenberg points out that the needs of people depend on the context of the meaning of life, and that people then base their judgements on what is good for them and supposedly for others (Pannenberg 1999:457, 458). The secular state, lacking the religious foundation for moral obligation and the authority of the law, however, justifies its power and rule by manipulating public awareness of its own needs and context of meaning (Pannenberg 1999:472). Failing the much-needed moral motivation, the secular state then secures its interests along the lines of manipulation, which Pannenberg (1999) explains as follows:

The 'context of meaning' is also the basis for the manipulation of needs. The manipulator influences the consciousness of meaning in a direction that is determined not by the quest of truth but by the (concealed) special interests of others. (p. 458)

Instead of serving the public, politicians in their own interest serve the others - meaning in many cases the mighty powers of finance and industry. Politicians are known to be masters of deceit. Served by their faithful bureaucracy, they manipulate and betray to get their way. Once the bureaucracy has its mindset in place, it tends to steamroll and trample everything in its way, whether right or wrong. Barth (2004:252) says a bureaucrat 'is always inhuman' (Barth 2004:252), because '[b]ureaucracy is the encounter of the blind with those whom they treat as blind'. To have this kind of inhumane and insensitive approach in life means, according to Barth's line of thinking, to treat other people in a way in which you never lay eyes on them - a predisposition where you never have to see (or want to see) the other person as a human being in front of you, a person with feelings, needs, aspirations, concerns and intellect. The bureaucrat indifferently treats and dismisses human beings as objects simply according to predetermined decisions, instructions and schemes. Barth (2004:252) says: 'In the process he may never see the real men and always be invisible to them.' There is not the slightest notion of morality here. Apart from the politicians and the bureaucracy, in referring to the powers of finance and industry, someone somewhere also reminded us: The captains of capitalism have no loyalty. The captains of capitalism expect everything from everyone in their service, but they in turn (in their faithless greed) use, misuse and then afterwards without any moral consciousness discard anyone who has faithfully served them for many years and long hours every working day. They give lip service to suggestions of moral corporate responsibility towards workers, society and the environment, whilst continuing on their radical, evil path, in being only concerned about satisfying their own ever-growing greed. Moltmann (2012) points out what we all know and experience daily:

For more than forty years, we have been continually hearing on every side the lament that the gap between rich and poor is 
getting wider and wider. A small, wealthy upper class dominates the masses of impoverished people, and not just in the poor countries of the Third World (I am still deliberately using this term even today). In the democracies of the First World too the gap between the top executives with their millions and the people living on social security benefits is becoming grotesque ... The liberty enjoyed by individuals and the wealthy classes becomes a public danger if 'privatize profits, socialize losses' becomes the ruling motto. (p. 47)

People's selfishness and greed inevitably reveals their propensity for destructiveness in the drive for more wealth and so-called progress. More than the freedom of the market, Jean-Jacques Rousseau (1712-1778) was in his time already more concerned about the freedom of man in need of realisation under the yoke of an oppressive society. The society criticised by Rousseau resembles what the majority of people, in some way, probably experience in modern-day societies across the world - in the sense of societies:

which bound new fetters on the poor, and gave new powers to the rich; which irretrievably destroyed natural liberty ... converted clever usurpation into unalterable right, and, for the advantage of a few ambitious individuals, subjected all mankind to perpetual labour, slavery, and wretchedness. (Rousseau 1963:205)

Rousseau's dialectical thinking leads him from a hypothetical freedom of the individual in the natural state, through the antithesis of freedom for some in the oppressive society of his time, to the synthesis of the new society of $D u$ Contrat Social (1762), in which democracy accomplishes freedom for all through morality (cf. Labuschagne 1987:1024, 1033-1046). Of course, many democracies today are really very far from freedom for all in terms of ethics. Rousseau's wisdom echoes what Aristotle (384-322 BC) said more than 300 years before Christ, on the challenge of taking all of society into account (in kingship, aristocracy, or constitutional government) and not ruling in any of them 'to the advantage of one section only' (Aristotle 1975:115). Aristotle (1975) explains:

The corresponding deviations are: from kingship, tyranny; from aristocracy, oligarchy; from polity or constitutional government by the many, democracy. For tyranny is sole rule for the benefit of the sole ruler, oligarchy for the benefit of the men of means, democracy for the benefit of men without means. None of the three aims at the advantage of the whole community. (p. 116)

Focusing on the overwhelming immensity of humanity's selfishness and greed in our world of the 21st century, we ought to hear Jürgen Moltmann's (2010) warning against the outcome of people's ruthlessness in this regard:

There will be no human life after the nuclear winter. Regardless industrialization at the expense of nature, the irreversibility of man-made global warming, and the inability to retract the contamination of the earth, the oceans and the atmosphere these things have made mortal and destructible the organism of the earth in which, and from which, human beings live. (Moltmann 2010:38)

The modern nihilistic destruction of nature is nothing other than practised atheism. The perpetrators are excommunicating themselves from the community of creation (Moltmann 2010:32).
The worldwide banking crisis is currently drawing a lot of criticism due to the austerity measures and the amounts of taxpayers' money needed to redeem the problems of the bankers' greed. On 03 March 2013 BBC News reported on the Swiss referendum which backed executive pay curbs: 'Nearly $68 \%$ of the voters supported plans to give shareholders a veto on compensation and ban big payouts for new and departing managers', and, '[o]rdinary Swiss are concerned about a growing economic divide in the country' (BBC News Europe 2013).

Although vastly outnumbered, there is always a small minority in the high places of politics, finance and industry, whom we deeply admire for their Christian example and moral courage. Nevertheless, the lesson of history remains: What awaits humanity in future and especially those in high places will always and inescapably be, irrespective of changing circumstances and challenges, the scrutiny and the judgement of ethics. Accountability for one's deeds will somehow always catch up with one. In history, the trials after wars and socio-political and economic turmoil testify to this truth.

\section{Ethics and the dynamic concept of humanity}

Reflecting on ethics and the anthropological foundation of ethics, the question that continually arises remains: Who is this restless being, called man, really? Clearly, in view of what has already been said, the indications are that there are many complexities relating to and surrounding human existence and the ethical issues related to being human. A specific picture of humankind now comes to the fore. Barth's understanding definitely makes sense when his theological anthropology presents us with a dynamic concept of a human being. Barth (2004:248) himself says: 'Nor is this human being static, but dynamic and active' and, 'I am in encounter' (Barth 2004:247). A person is dynamic within a relational context. We become ourselves in relation to others.

Against the background of Barth's dynamic concept of humankind, however, there are two assumptions with their origins in the 19th century that need to be examined. The one degrades humankind to a mere object. The other depicts humankind as a captive within the boundaries of the subjective human mind. These two implicit assumptions, in terms of either objectivism or subjectivism, create a dualism in Western philosophical understanding of humanity.

In his theological anthropology Barth pushes beyond such an anthropological dualism. Barth presents a dynamic concept of humankind, in which the dualism is overcome, explaining a human being to a significant extent as a unitary acting agent, realised through interpersonal relations. Dynamic refers to motion - that constitutes acting and making choices, including ethical decisions - in interpersonal relations. In all of this, Barth stresses the view of the whole man (cf. Price 2002:234-280). 


\section{Dynamic anthropology: The whole person - acting consciously and dynamically}

Highlighting the whole person subsequently reveals that acting consciously and dynamically upon our world, we are more than a combination of biochemical impulses acting mechanically, and also more than an autonomous thinker captured within the confines of a physical body. Barth rejects both opposites in this dualism. Man is more than merely a mechanical body on the move within the parameters of the natural sciences. Man is more than an autonomous thinker captured within the confines of a physical body (in terms of the practical reason of Immanuel Kant [1724-1804] or Liberal Theology, from Schleiermacher [1768-1834] to Tillich [1886-1965]). In response to both opposites, the theological anthropology of Barth offers vastly more: The dynamic concept of the whole human being avoids the one-sidedness and the confines of both cases.

A human being is indeed in essence a being acting consciously and dynamically, making choices in relation to all human doings and involvements, interacting with the world, and surely this includes moral choices challenged by the inescapable demands of responsibility in all human conduct. Barth (2004:127) highlights humanity's 'spontaneous aspects in his own concrete choice and act' and in this sense 'his freedom must be understood as his capacity for decision.' Man's 'being as an ability to be must be interpreted as the constant seizure of his own possibility' (Barth 2004:127).

Barth (2004) explains this in somewhat more detail. Humanity learns 'to know the actuality of his existence' as:

an ability to be, a sequence of actions in which he constantly re-posits himself in his conscious or unconscious thinking and willing in relation to another which he may well think of as the wholly other, as God. He thus discovers himself in his freedom; and especially in our discussion of the ... ethical stage of human self-understanding we have noted how this awareness can be enriched and deepened in detail. Being in the sense of human being is a process of self-enactment. ... There can be no being or self-enactment without experience. He is as he learns. It is the manner of his freedom to be 'rational' in this sense. He can now see and say that between ... man and the other ... there is reciprocity, so that human being on its active side can and must always be understood as a reaction to these experiences, as an answer to the communication which comes to him. To be a man is to be responsible. To be a man is to respond to what is said to man. The spontaneity of man consists in the fact that he is capable of this responsibility. In each of the acts in which he constantly re-posits himself man exercises this capacity. His freedom is his freedom to participate in this reciprocal action. (p. 126)

Acting consciously and dynamically also involves seeking a meaningful existence in the world in which human beings find themselves. Part of this necessarily and especially leads to seeking meaningful relations with all other personal beings encountering them on life's path.
Accepting a human being as merely a mechanical body on the move within the parameters of the natural sciences has its background in a new and anti-metaphysical philosophy, which developed since the middle of the 18th century. This philosophy, together with its corresponding popular way of thinking, came to be known as modernism.

Many would later specifically see the 19th century as predominantly the age of modernism. Modernism sees humans, and then not only their bodies but also their minds and entire spiritual life, as an object to the methods of the natural sciences. Within the reach of bare factuality, people are seen as being integrally part of the whole of the natural world. Furthermore, modernism also considers the whole of the natural world as most essentially controlled and guided by natural laws. The habit of modernism is to understand humanity in its entirety as simply just another scientific object, similar to any other object for empirical observation and experiment - just another ' $i t$ '. This oversimplification of modernism indeed then applies even to all the complexities of the human mental world, its deepest emotions, intense anxieties and dearest longings, its unshared and sensitive moments, its sometimes very close connectedness to other human beings, its relatedness to and interaction with human society, the animal world and the natural environment (cf. Scott 1978:218-221).

Existentialism essentially and persistently rejects the assumption of modernism, which reigned for too long, namely that objective empirical science 'affords a sufficiently comprehensive basis for the interpretation of man' (Scott 1978:221). Existentialism stands in opposition to what now can be seen as modernism's misjudging of humanity, particularly the degrading of the individuality and uniqueness of the human inner self to the level of a mere, objectified 'it'. The sciences of anatomy and physiology and also other natural sciences cannot provide answers to people's search for a deeper understanding of themselves and their destiny as human beings, and there is more to humanity than merely being caught within the limits of a qualitative formula (cf. Scott 1978:220-221).

Existentialism, with prominent figures such as Martin Heidegger (1889-1976) and Jean-Paul Sartre, especially addresses what might be called the existential problems and experiences of humankind: the challenges and emotions of human existence, as individually and uniquely experienced. In existentialism's thinking, existence confronts man with the search for meaning, the meaning of existence, the meaning of 'dasein' (of 'being there'). The search for the meaning of being human involves existence, dasein, being thrown upon oneself amidst such very human experiences as freedom, responsibility, longing, love, nostalgia, suffering, alienation, fear, anxiety, despair, as being alone in the world, as being aware of humanity's destiny of death. Living one's own life, making one's own decisions, existing according to one's own design as dasein, the individual, without contours, is continuously creating himself or herself in an ongoing process, knowing no other way. On the basis of the human 
mind's subjective contemplation of the existential need of something more (love, comfort, guidance, hope, grace, etc.), some might even explain the experiences of certain events in their human existence as having some kind of reference to God (cf. Bochenski 1966:155, 159; Scott 1978:225-227; Labuschagne 1987:217-220). The approach to God surely says something about one's understanding of oneself. However, whatever these existential passions, suffering, needs, aspirations, hopes and challenges might be, they all lead to choices, decisions and conduct, all understandably human, and therefore eventually always under the scrutiny and judgement of ethics.

In spite of existentialism's contribution in countering modernism's degrading of people to a mere object of science, existentialism falls victim to its own one-sidedness of a hermeneutics constricted to the confines of the subjective human mind - with its origin in the Kantian tradition.

Barth's criticism against the subjectivism of Kant's moral philosophy and Kant's autonomous human mind (practical reason) is also applicable to the subjectivism of existentialism. Again Barth responds with the dynamic concept of the whole human being. Both objectivism and subjectivism fail to reach the whole human being. For Barth the individual person, the whole man, comes into the picture in terms of interpersonal dynamics and interaction, and a person can be adequately described only when that person's interpersonal history is taken into account. Barth's thinking here is in line with object relations psychology, where the whole self is formed biologically within the womb of the mother, and psychologically and spiritually within a social matrix. Regarding the influence of the social environment, especially the early relations between parent and child are fundamental to one's becoming oneself - that is apart from the imprint of the different dimensions of society on humanity (cf. Price 2002:235). Certain important relations that man can have with others, in what is called an 'outer dynamic', can have such an impact on a person that it becomes internalised and a serious determining issue in that individual's psyche, thus becoming an 'inner dynamic' (cf. Price 2002:231). A very real, serious moral burden is indeed the consequences of one person's convictions, behaviour and influence on other people, adult or child, and on what becomes of them. It is terrifying to be reminded of the realisation of having a responsibility for the good of others, as something one can never escape from. And then to make it even worse: we stand before our Creator and God as sinners - the sickness unto death.

The hermeneutics of being constricted to the human mind does indeed become apparent in liberal theology's adherence to existentialism. Determined by their existentialist hermeneutic strategy, we can identify two ways of thinking about God in the theologies of Rudolf Bultmann (18841976) and Paul Tillich - and this has direct bearing on their understanding of man. Firstly, the word 'existential' defines God, in terms of the human attitude, as ultimate concern, and for the 20th century this involved humankind's 'quest for meaning' (Bultmann, Tillich). Secondly, the word 'ontological' defines God as 'Being itself', and that refers to the reality which is itself not a being (Sein) or anything that is, but that which is present in and beyond all beings as the source of their existence - Tillich (cf. (Macquarrie 2003:301). In response to the emphasis on the human mind as the sole basis of our understanding in Kantian moral philosophy, existentialism and liberal theology, Barth was explicit in his theology that the sovereign God, in every possible expression of god-talk, could never be an extension of the human mind - the human mind then as last resort. For Barth, God can never be the immanent possibility of human reason (Kant) or human affections (Schleiermacher) (Price 2002:133). Pannenberg emphasises that humankind does not have the capability, rationally or philosophically, to know God: 'To know God is no constituent part of our natural endowment from birth' (Pannenberg 1977:50). He refers to the conception of reality as history, and then explains that the biblical understanding of God does not follow from humankind's endeavours and philosophical deductions, but from reality, as a history of ever-new events, which makes ever-new demands on the personal decision of man. This reality (as a history of ever-new events) reaches in the end of all history (which indeed has already occurred) the demonstration of the deity of the one God revealed in Jesus Christ which is superior to philosophy (Pannenberg 1977:60, 61). Pannenberg (1977) adds:

If by the special character of the events connected with Jesus, God is not hidden but wholly revealed, then he cannot be equally revealed in some other form ... That is why Karl Barth rightly repeated so constantly and emphatically that God is revealed only in Jesus Christ. But if it is only on the basis of the Christ event that it is possible to say who God is, then God's being cannot be thought of without Jesus. That is the meaning of the statement that Jesus himself is God, the Son of God and one with the Father ... The Spirit of truth of this recognition is therefore once again God himself. Thus the self-revelation of God in Jesus is the root of the recognition of his deity and of the doctrine of the Trinity. (p. 60)

Therefore, what a person knows of God, is revealed to them by God, in and through Jesus Christ, and not through some immanent possibility of the human mind.

Nevertheless, for the existentialists true knowledge is not achieved by object-related understanding, but only subjectively, through experiencing reality (cf. Bochenski 1966:160). Nevertheless, Heidegger does not make a final choice for atheism, unlike Sartre. Heidegger quite humbly keeps an open mind on God, and other possibilities, but never finds a way out of the human impasse of being thrown into this world to find oneself and one's own way, and of being alone in this world (Labuschagne 1987:232234). It is significant that existentialists like Kierkegaard (1813-1855) and Gabriel Marcel (1889-973) are confirmed theists (Bochenski 1966:160). Heidegger says that to have faith in a reality beyond this world, and to try and prove or assume such an existence, implicates a subject which is in the first place without a world or uncertain of its world (Heidegger 1935:206). And yet, he does not accept that anyone can now jump to the easy conclusion of atheism from 
the Nietzschian dictum: 'God is dead' (Heidegger 1973:58). With the existential determination of humankind's being, nothing as yet has been made out concerning the existence or non-existence of God (Heidegger 1973:61). Heidegger (1973:60) adds: With the statement of 'being in the world' as fundamental feature of the humanitas of homo humanus it is not said, in the Christian sense, that man is only a being of this world, and thus without God and any transcendental possibility.

It is rather astonishing that, whilst an existentialist philosopher like Gabriel Marcel confirms a theistic God, and an existentialist philosopher like Heidegger keeps an open mind on the matter, an existentialist theologian like Tillich rejects outright the existence of a personal and theistic God. Tillich refers to the God who appears when God has disappeared in the anxiety of doubt' (Tillich 1974:183). Hence, Tillich argues for a new understanding of a God who appears when we are able to break away from a theistic objectifying of God and a theistic understanding of a personal encounter with the living God. In Tillich's existentialist understanding of God, the whole theistic approach disappears in what he sees as the abyss of meaninglessness.

What is traditionally ontologically understood in the church as the being of the deity, is something which Bultmann chooses to understand as referring not to a being (or the being of God), but to an event. This event then, is such that humankind can experience it existentially - as the event of God's action (cf. Macquarrie 2003:295, 296). Despite the Early Church's confession of 'the full divinity of the Son', confirmed at the First Ecumenical Council of Nicaea (325) (cf. Lohse 1985:50-56), Bultmann still claims: 'Christ's Lordship, his deity, is always only an event at any given time' (Macquarrie 2003:295). Christ's deity is, in this view, only an event experienced by humankind.

\section{Dynamic anthropology is open-ended}

Barth's concept of humankind has to be understood as relational and not mechanical nor as encapsulated by subjectivism. For Barth, the individual person described in terms of interpersonal dynamics is explicitly not a closed system, but an open-ended ongoing process (Price 2002:235). Thus, as relational beings, we are ever becoming ourselves. We become ourselves in relation to others, in the reciprocal acts of freedom and responsibility. Freedom and responsibility can never be seen without ethics, without the distinction between right and wrong. To act in a responsible way will necessarily always pose the question: But did you do the right thing? To act in whatever way can never free one from the consequences of being responsible for one's own deeds. In short: Freedom and responsibility affect humanity's ability to be open-ended and therefore an ongoing process. In the words of Barth (2004):
[B]eing ... is an ability to be, a sequence of actions in which he constantly re-posits himself in his conscious or unconscious thinking and willing in relation to another. (p. 126)

On the everyday open-ended path of finding an own identity, one is really, by one's own actions pictured to oneself and to the world for all to see and to evaluate morally. If the motion picture of one's life spells out the lack of a basic moral consciousness in terms of some or all of the following: deeds of untidiness, sloth, no self-respect or respect for others, a total lack of integrity, arrogance, permissiveness, deviance, greed, dishonesty, corruption, aggression, horrific acts of violence, mass brutality and gangster mentality hidden behind mass action and bureaucracy, and lawlessness - then that is the identity one is portraying of oneself. One is then manifesting, morally, anything from a failure, a loser and a pervert to a repulsive and sickening monster. People with this kind of identity profile are found in all ranks of society, ashamedly also in high places. Some countries are even notorious for their societies being contaminated in this way.

Reflecting on anthropology, we are bound to discover that anthropology indeed always involves ethics. In terms of being human in relation to others, the consequences are (in the event of our interaction with others) that we have to accept responsibility not only for ourselves (for what we are becoming), but also for the effect of our bad behaviour and influence on others. Regrettably, the effects of ill behaviour go on, even after we have refrained from our gross misconduct, because our influence on others is also open-ended, an ongoing process. Becoming oneself is an open-ended process. The tragedy is that we shall never know where our bad influence will eventually lead - but in terms of moral responsibility, we are inescapably implicated. Remember that we are morally our brother's keeper. We always need to take the well-being of others into consideration (cf. Gn 4:1-15). Sometimes we even need to protect people from harming themselves. We have a moral choice to make, every day in the interaction with others, for ourselves and for others. Positively, we could be the salt and the light of the earth - for the well-being of ourselves and for others (Mt 5:13-16).

\section{Ethics in relation to dynamic anthropology as Trinitarian anthropology}

Whatever we think, feel or do, is always in conjunction with who and what we are as human beings, and we are ever caught within the inescapable web of moral evaluation.

\section{Humanity going beyond the understanding of oneself as a natural being}

Who humankind is, is for Barth (2004:19) essentially revealed in the relationship between God and man: 'Man is made 
an object of theological knowledge by the fact that his relationship to God is revealed to us in the Word of God.' To have a clear mind on what precisely Barth means by the 'Word of God', it needs to be said that for Barth, Jesus Christ alone is the Word of God. From the basis of Jesus Christ being alone the Word of God, the Bible is now the Word of God in its relation to Jesus Christ and through the witness of the Holy Spirit. In Barth's (1963) own words, in short:

God's revelation takes place in the fact that God's Word became man and that this man has become God's Word. The incarnation of the eternal Word, Jesus Christ, is God's revelation. ... Scripture is holy and the Word of God, because by the Holy Spirit it became and will become to the Church a witness to divine revelation. (pp. 1, 457)

In short, we as humans learn to understand who and what we really are as human beings, in our relation to the Word of God that became man in Jesus Christ.

Barth represents a major shift in thinking in theological anthropology when his understanding does not focus on man as supposedly determined by his own innate faculties, but when his understanding focuses on relation (cf. Price 2002:117).

Furthermore: Understanding the ongoing link and tension between anthropology and ethics, Barth says man 'thus exists in tension ... between his natural and his moral life' and 'can see and understand himself only as a possibility and never as actuality. He exists in the historical reality resting on these tensions' (Barth 2004:111). Seeking after the 'mystery of himself', we humans need to go beyond what we can understand of ourselves as natural beings. We need to advance from nature to freedom, to the uncertainties of seeing ourselves as ethical beings, and this involves an ongoing process in which man 'transcends himself, and therefore is always in search of himself' (Barth 2004:110, 111).

In elaborating on humanity's going beyond the understanding of itself as a natural being, in search of itself, Barth (2004) finds the answers in the encounter of man with God in the 'existence of the man Jesus'. We need to find ourselves in relation to the man Jesus:

The history of a being begins, continues and is completed when something other than itself and transcending its own nature encounters it, approaches it and determines its being in the nature proper to it, so that it is compelled and enabled to transcend itself in response and in relation to this new factor. The history of a being occurs ... when it is transcended from without so that it must and can transcend itself outwards. (p. 158)

Elsewhere he says about our human essence meeting us in the man Jesus:

We are shamed because our human essence meets us in Him in a form in which it completely surpasses and transcends the form which we give it. In Him we are not encountered by an angel, or a being which is superior and alien to our own nature, so that it is easy to excuse ourselves if we fail to measure up to it. We are confronted by a man like ourselves, with whom we are quite comparable. But we are confronted by a man in the clear exaltation of our nature to its truth, in the fulfilment of its determination, in the correspondence to the election and creation of man. We are confronted by the man who is with and for God as God is with Him, at peace with God and therefore with His fellows and Himself. But this means that we are all asked by Him who and what we ought to be as His brothers. The measure by which we are measured is the true man in whom the true God meets us concretely in a living encounter. Compared with Him we stand there in all our corruption. The failure of all that we have and do is revealed. (Barth 2000:386)

In order to eliminate any misunderstanding regarding Christ in one Person simultaneously in his divinity and his humanity, Barth pointed out significantly, a few sentences earlier: Christ is 'very man even as He is very God' (Barth 2000:385, 386)

\section{Imago Dei as relationship to the Word of God}

In his theological anthropology, 'Barth interpreted the imago Dei as being in relationship to God. Barth denied that humans possess an inherent a priori potential to form the relationship' (Price 2002:117). Imago Dei primarily refers to the act of God's creating a relationship between God and ourselves as humans, and from there, a relationship between ourselves and others. Not humankind, but the Word creates the relationship between God and people. Regarding 'the object of faith', Barth (2008) stresses that humankind:

has not created his own faith; the Word has created it. ... the Creator encloses the creature and the merciful God sinful man, i.e., in such a way that man remains subject, and yet man's I as such derives only from the Thou of the subject God. (pp. 244, 245)

Thus, man becomes a person through the I-Thou relation with his Creator. God created everything through the Word: 'The Word was the source of life' (Jn 1:3, 4). In short: we become ourselves in the I-Thou relationship (Imago Dei) which God created through the Word (Christ). In the image of God, we inevitably find ourselves in relation to the Word of God.

To be able to know something about God, who reveals himself and the human believer through the encounter with his Word, is not something which corresponds to some 'human possibility'. The reason for this: 'the knowability of God's Word', is really 'God's work alone', and for humanity the experience of 'an inalienable affirmation of faith'. This is important:

we must also understand that man must be set side and God Himself presented as the original subject, as the primary power, as the creator of the possibility of knowledge of God's Word ... But the fact that this takes place is ... the work of the Christ. (Barth 2008:247)

The man Jesus is the ontological basis of all humanity. Barth explains his understanding of humanity created in the image of God in terms of the humanity of Christ. Everyone who 
bears the name of man, 'stands in an indisputable continuity' with the 'One' who is 'from the very outset ... the Neighbour, Companion, and Brother of everyman' - the 'ontological basis' of man (Barth 2004:134, 137). However, it is significant that Barth does not break with the Christological formula of una persona in duabus naturis [two natures in one person], which in the larger context of the history of theology reaches its 'decisive apex' in the Confession of the Fourth Ecumenical Council of Chalcedon (451), and was already strongly evident ('simultaneously, though independent of one another') in the thinking of the unmixed unity of the two complete natures (of the divinity and the humanity) in one and the same Christ in Theodore of Mopsuestia (350-428) and in Augustine (Drobner $2007: 325,321,485)$. This means that imago Dei, as the point of contact between God and man, which some theologians hold to be inherent in human nature, is now understood by Barth to reside in an ontological relationship with the One who is actually both Son of Man and Son of God. Whilst it is the man Jesus who is the ontological basis for the understanding of all humanity, it becomes quite clear in Barth's argument that he nevertheless never separates the humanity of Christ from the divinity of Christ. Barth (2004) says: 'Jesus [is] the divine Counterpart of every man' and adds:

Certainly it is a transcendent and divine Other which constitutes man. ... this divine Counterpart of every man, of man as such, is concretely this one man in whose creaturely being we have to do with the existence, the saving act ... the fulfilment of the will of God - with the creaturely being existing for God. (p. 134)

Clearly, he does not confuse or mix the divinity and the humanity of Christ.

\section{Trinitarian anthropology - analogia relationis}

Dynamic anthropology is concerned with man becoming himself in relation to others, whilst still differentiating each individual and group. For Barth to explain ethics on the basis of a human being as a relational being, the anthropological foundation of ethics needs to be explained in terms of a Trinitarian anthropology. Trinitarian anthropology is to be understood in the light of the self-revelation of God in Jesus Christ, in history. The core of Barth's Trinitarian anthropology is the concept of analogia relationis - referring to a resemblance of relation between the Triune God and humanity:

There is an analogia relationis. The correspondence and similarity of the two relationships consists in the fact that the freedom in which God posits Himself as the Father, is posited by Himself as the Son and confirms Himself as the Holy Ghost, is the same freedom as that in which He is the Creator of man, in which man may be His creature, and in which the Creator-creature relationship is established by the Creator. We can also put it in this way. The correspondence and similarity of the two relationships consists in the fact that the eternal love in which God as the Father loves the Son, and as the Son loves the Father, and in which God as the Father is loved by the Son and as the Son by the Father, is also the love which is addressed by God to man. The humanity of Jesus, His fellow-humanity, His being for man as the direct correlative of His being for God, indicates, attests and reveals this correspondence and similarity.... it follows the essence, the inner being of God. It is this inner being which takes this form ad extra in the humanity of Jesus, and in this form ... remains true to itself and therefore reflects itself. (Barth 2004:220)

The 'material necessity of the being of the man Jesus for His fellows' rests on the 'mystery of the purpose and meaning of God, who can maintain and demonstrate His essence even in his work, and in His relation to this work' (Barth 2004:220).

In terms of analogia relationis, God reveals himself as relational in the Trinity, in the relation of the Father, the Son and the Holy Spirit. That is relational towards himself. But God also reaches out and creates humankind in relation to himself. Analogous to God's likeness as relational being, man is now also a relational being, meaning a relational being in humanity's relation to God. This is the meaning of imago Dei.

Neverteheless, imago Dei reveals further relations. The analogia relationis goes on. When God creates human beings in his likeness, he distinguishes between a man and a woman. He creates a man in relation to a woman. That means: As there is relation in the Trinity, there is also relation in man, in the distinction between a man and a woman. And from there, all other relationships between human beings need to be understood. Therefore, in comparing God and man, there is resemblance of relation - analogia relationis.

We become ourselves in relation to God, and from there, in the first place, in the relationship between a man and a woman. And we become ourselves in the encounter with all other human beings. Through bad relations instigated by ourselves or other people, in terms of ethics (cf. Eph 4:22-24), we become bad people. Bad friends, bad clubs, bad groups, bad company of any sort, an evil society of villains and fraudsters in all structures of society, lead to myself being everything bad. Especially in the mentality of the arrogant hordes, humanity becomes its own doom and worst enemy. Humanity's sinful inclination inevitably has a far-reaching detrimental effect on the surrounding world, including society and the natural environment.

We are constantly in need of a new beginning for humanity - in view of mankind's radical harmful effect on every aspect of any relationship, towards whoever or whatever. Approaching the challenge of a new beginning involves aspects such as human distinctiveness, creatio continua, restoration and salvation, messianic ethics and eschatological Christology.

\section{The interpretation of imago Dei as way of defining human distinctiveness}

J. Wentzel van Huyssteen argues for a 'postfoundationalist approach' in a transversal inquiry (interdisciplinary research) on human uniqueness as directly associated with the 'biblical claim that humans are created in the image of God' (Van Huyssteen 2006:xv, 159). In conclusion, he distinguishes five 
categories of understanding, from which significant aspects can be abstracted (Van Huyssteen 2006:159-162):

1. Traditionally, the many different understandings of the concept of imago Dei have always somehow expressed relationship - relationship between Creator and creatures, God and human beings.

2. Imago Dei portrays human beings as in no sense more important than 'other animals', but nonetheless endowed with ethical responsibility towards the world. Referring to knowing good and evil in Genesis 3:22a, Van Huyssteen points to 'the emergence of an embodied moral awareness', claiming 'in this important text is embedded the most comprehensive meaning of the biblical notion of the imago Dei'. In the New Testament Jesus Christ is now, in terms of imago Dei, identified as the one who defines the relationship between God and humanity, and, 'what we know of God, we know only through the story of the suffering and resurrection of the embodied person of Jesus.'

3. An analysis of the many different views on imago Dei in recent theological history reveals the danger of disembodied, abstract interpretations in some substantialist, functionalist, relationalist, existentialist, and eschatological interpretations. Van Huyssteen endeavours to create a 'transversal connection between the best of intentions of these many models for imaging God' in order to escape disembodied abstraction and reach the powerful source needed for direction in human life, for the embodiment of discourse with God and with one another. And: 'This view presupposes that the embodied human person has biologically emerged in history as a center of self-awareness, religious awareness, and moral responsibility.'

4. Feminist theology has also influenced contemporary thinking on imago Dei, when it reveals the 'liberating character' of imago Dei - in the sense of avoiding speculative abstraction, in moving 'towards embodied human persons', as powerful source for the accomplishment of justice, liberation, and reconciliation. Feminist theology does this when practically doing something to counter discrimination against and oppression of women, and then on the important basis of all humans being equally created in the image of God. From here follows much more in terms of 'a liberating ethic of interhuman relationships and ecological responsibility'

5. In our present highly complicated world, there are questions on human uniqueness confronting theology, which call for a more holistic and embodied approach. Going back to the resources of theological traditions alone might not be adequate. Van Huyssteen, in these circumstances, argues for 'the public voice of theology', reaching out across disciplinary boundaries in search of answers:

Finally, a postfoundationalist approach to the problem of human uniqueness in theology not only reveals a more holistic, embodied way to think about humanness, but also argues for the public voice of theology in our rather complex contemporary culture. (p. 162)

\section{Understanding humanity and nature as creation - creatio continua}

It is always venturesome to reach out to the metaphysical world, in order to search for knowledge about humanity and its world - on the basis of some sort of contact to be made by the human mind with the world beyond (as philosophy since Plato and Aristotle somehow suggests), or even on an assumed resemblance or analogy of being between God and humankind (analogia entis) in the thinking of Thomas Aquinas (1225-1274). In this regard, the endeavours of the human mind were really a continuing process through the centuries. However, many theologians through all times rejected this approach as the aspirations of the human mind and, as such, an impasse in which no progress was possible - knowledge of ourselves and nature was not to be deduced from a being or an idea. Barth, for instance, in strongly opposing these contentions, preserved both the transcendent freedom of God to reveal himself in Christ and also the indirectness of revelation - meaning that God could never be the immanent possibility of the human mind (human reason or human religious affections) (cf. Price 2002:132-133).

Attempting to understand something of the basics of creation, which indeed directly affects our understanding of humankind, Moltmann (2010:202-206) discerns the following crucial aspects:

- 'The ancient Greek concept of physis does not make any distinction between what is divine and what is worldly. Physis is the power of producing, of generation, and it is hence divine. Understood as physis, the cosmos is of divine perfection.'

- Theologically, the world is to be understood as creation, and 'as creation, it cannot be divine like its creator, ... it cannot possess any divine attributes.' Creation has its 'foundation not in itself but in another.'

- The universe is the creation of a transcendent God and has its origin in his free will, but 'is not a necessary expression of his being, although it corresponds to that being. So it is contingent (contingentia mundi).'

- The modern empirical concept of the world and of nature 'by no means contradicts the theological concept of creation ... it corresponds to the theological concept and results from it'. Theologically, philosophy's metaphysical concept of nature was unacceptable. Theologically, nature 'can be known only through observation and investigation, not deduced from a being or an idea.'

- Then there is the aspect of everything being in a state of becoming itself. Moltmann says: 'Self-transcendence is ... characteristic of all created things.' God's creation (man/ nature) is from the beginning indeed a:

changeable world (mundus mutabilis), a world in movement, in which every living being can distinguish between past and future, reality and potentiality. If the world were suddenly to stand still, we should no longer be able to perceive time.

- Everything is in transition, between beginning and end. The future belongs to the kingdom of God. The 'present 
state of the world no longer corresponds to conditions as they were "in the beginning", nor is the world as yet the kingdom of God, as it will be at the end.'

- In response to our present world as a creation spoiled by sin, and threatened by the forces of evil and annihilation, Moltmann still believes in the God of a good creation, who will bring his creation to its perfect future in the kingdom of Christ - through continuous creation (creatio continua). He says:

In continuous creation God preserves those he has created, in spite of everything that threatens them and in spite of their sins. In it he anticipates their future in his kingdom ... he does not give up their future, but continually gives them new time and new future ... the God of Israel and Jesus Christ is a bearing, patient, enduring and suffering God. His rule... is a rule of love. His almighty power shows itself in his all-enduring patience. (Moltmann 2010:204-206)

Moltmann (2010) refers to God's sustaining energies in Christ as signs of his saving future:

The true revelation of the sustaining God is the suffering Christ on the cross. 'He has borne our sicknesses' (Is 53:4) and has taken on himself the sins of the world, in order to heal and to redeem. 'He upholds the universe through his word of power' (Heb. 1:3). (p. 206)

\section{A new beginning for humanity}

The anthropological view of the early Church indeed pointed towards a new beginning for humankind, and accordingly understood humanity's salvation in terms of restoration and re-creation. The early Church, surely, did not follow neo-platonism's separation of body and soul. For Irenaeus (pre-177 - c. 200) restoration is connected to the 'salvation of the complete man, that is, of the soul and body' (Irenaeus 2010a: Book V, 606-607). In many instances his ideas of humankind's restoration are comparable to the insights of John 14:6 (the way, truth and life): 'But the Lord, our Christ ... established fallen man by His own strength, and recalled him to incorruption' (Irenaeus 2010b: Book II, 211):

Our Lord also by His passion destroyed death, and dispersed error, and put an end to corruption, and destroyed ignorance, while He manifested life and revealed truth, and bestowed the gift of incorruption. (Irenaeus 2010a: Book II, 212)

[F]ollowing the only true and steadfast Teacher, the Word of God, our Lord Jesus Christ, who did, through His transcendent love, become what we are, that He might bring us to be even what He is Himself. (Irenaeus 2010b: Book V, [Preface] 553, 554)

When referring to God's intervention in Christ for the sake of man's restoration and salvation, Tertullian (c. $160-c .220)$ emphasises the whole person of man:

$[T]$ he restoration of flesh and blood, in order the more emphatically to express the resurrection of such bodies as have even been devoured ... Since, however, things which belong to the soul have nothing allegorical in them, neither therefore have those which belong to the body. For man is as much body as he is soul. (Tertullian 2007:568)

[T]hings which are destined for the body should be carefully understood in a bodily sense, - not in a spiritual sense ... (The) bodily character of the flesh is indicated by our Lord whenever
He mentions the resurrection, at the same time without disparagement to the corporeal nature of the soul. (Tertullian 2007:569)

The view of a new beginning in the combination of restoration and salvation was well established by the time of Augustine (354-430): 'He who made us remade us because we were lost' (Augustine 2003:7).

The New Testament studies of Johannes Weiss (1863-1914) and Albert Schweitzer (1875-1965), at the end of the 19th and beginning of the 20th century, focussed on what they saw as Jesus' eschatological-apocalyptic teachings on the Kingdom of God.

According to Weiss and Schweitzer, 19th-century liberal theologians were not able to come to terms with the reality of the New Testament eschatology; they made Jesus the vehicle for their own 19th-century bourgeois moral values, and in spite of their concern for history, they in fact became quite unhistorical in their approach to Jesus (cf. Macquarrie 2003:274-277).

The second half of the 20th century heralded a renewed interest in the eschatology and the future of mankind, in theologians like Moltmann (1926-) and Pannenberg (1928- ). Moltmann's views on a new beginning for man, and what he calls the 'rebirth of life', is impressive in its promising substance. He compares the past as the 'age of beginning' to the future as the 'new beginning', 'a beginning in the end'. Moltmann (2010) elaborates:

We cannot prolong the era of beginnings and progress without seeing in front of our eyes the era of annihilations and end. If there is to be a new age ... it would have to be ... the new beginning. The symbol for this is not unending progress. It is the resurrection into life in the midst of the world of possible universal death ... The Christian message in this situation can be reduced to a simple formula: by virtue of his resurrection, Christ's end in the catastrophe on Golgotha became the true beginning of his new life for us. His raising from the dead shows the divine power of beginning in the end. That is the rebirth of life and the force of freedom. (pp. 38, 39)

Moltmann (2010) portrays man's future as the resurrection of life, in terms of a 'bodily gestalt or configuration':

By the living, lived body we do not mean the desouled body as an object ... we mean the experienced and lived body with which I am subjectively identical ... Real life is the bodiliness which I am ... (pp. 60, 61)

He refers to the apostle Paul in Romans 8:11, 22 and 1 Corinthians 15 and Philippians 3:21. In 1 Corinthians 15 he calls the same process 'changing', transformation, and in Philippians 3:21 he looks to the 'glorious (transfigured) body of Christ'. Transfiguration, finally, anticipates the transmutation into the beauty of the divine life. According to all these ideas, what comes into being after death in the place of mortal life is not a different life. It is this mortal, this lived, and this loved life which will be raised, healed, reconciled, completed, and thus find its divine destiny; for 'God created man for eternal life' (Wis. 2:23) (Moltmann 2010:61, 62). 
On man's transformation into a new life, Pannenberg (1976) states quite clearly that resurrection does not imply a disembodied spirituality.

Paul made it unequivocally clear that for him 'resurrection from the dead' did not mean the return to earthly life, but a transformation into the new life of a new body. In 1 Cor. 15:35-56 Paul expressly deals with the question how we ought to think of the physical reality of the person raised from the dead. Here it counts for him as being a settled thing that the future body will be a different body from the present one; it will not be a physical body but - as Paul expresses it - a 'spiritual body' (1 Cor. 15:43f.). What he means by this is not a disembodied spirituality, in the sense of some Platonic tradition or other ... Paul describes the relation of the immortal, spiritual body to the present mortal, physical body as a radical transformation ... On the other hand, however, it is this present earthly body which will experience the transformation; so that the transformation stands in a relationship to our present existence. What is to be created in place of the present body is not something totally different from it. ... What Paul has to say here does not apply in the first place to the resurrection of Jesus especially; his subject is the resurrection which Christians have to expect. For Paul, however, the two belong together. In his view, the resurrection of Jesus justifies Christians in hoping for their own resurrection. It is of the greatest importance for him that Christians should participate in that particular reality which has already appeared in Christ (cf. Moltmann 2010:31, 80).

Moltmann (2010) concludes:

The nineteenth century believed in Jesus' message about the kingdom of God and by way of that wanted to realize humanity's dreams. In the twentieth century people experienced plunges into the abyss of annihilation, the universal Good Friday. Today the essential thing is to believe in the power of the resurrection, and to prepare the way for the kingdom of God in the context of today's apocalyptic horizons. (p. 39)

The 'indwelling presence of Christ' is not restricted to his church alone; he is not only there for man's salvation but also for the good of all that exist (Moltmann 2010:31). God's renewal for the future involves man and the whole of his surrounding world: 'men and women are bodily and natural beings, and belong together with nature', they cannot be separated from nature and earth, not in resurrection, not in last judgement (Moltmann 2010:136). The 'coming Christ is also the cosmic Christ (Col. 1:15-17)' (Moltmann 2010:141). The coming Christ also brings rebirth of life to the social environment - in Moltmann's (2010) words:

The one who will come as judge of the world is the one "who bears the sins of the world' and who has himself suffered the sufferings of the victims of injustice and violence ... The victims of $\sin$ and violence will receive justice. They will be raised up, put right, healed and brought into life. The perpetrators of sin and violence will receive a justice which transforms and rectifies. (pp. 136, 137)

Israel's hope was directed towards the universal, cosmic indwelling of God in creation, and that through this indwelling, creation will be newly created and then eternal, according to Moltmann (2010):
With Christ, God's indwelling takes on a body, a face and a name. 'In him the whole fullness of deity dwells bodily', says Col. 2:9. The kingdom of God is the perfected perichoretic unity of God and world. (p. 30)

Christ's indwelling presence and his kingdom is about all things participating in his eternal livingness, just as he shares in their finitude - including their pain, misery, hunger, dying. (cf. pp. 31, 80)

The divine and the human, the heavenly and the earthly will interpenetrate each other without intermingling. God in all things and all things in God: that is what is meant biblically by the kingdom of God. When at the end Christ hands over 'the kingdom' to the Father, then 'God will be all in all' (1 Cor. 15:28). (pp. 31,32)

\section{Messianic ethics and eschatological Christology as its determining factor}

For Moltmann, 'Christian ethics is always stamped by the Christology it premises' (Moltmann 2012:37). Within the context of his Christology as an eschatological Christology, he explains his ethics as 'messianic' ethics (Moltmann 2012:37). This involves an ethics in which the present is already in the grip of the future, so that we see and experience that in the death and resurrection of Jesus Christ the Kingdom of God is already unfolding in the world. In the unfolding of the Kingdom the Trinitarian understanding of Moltmann also becomes apparent - in a world passing away, in transitory time, into an eternal future (cf. Moltmann 2012:37-39). Moltmann (2012) explains:

I developed my own Christology in dispute with the Christology of Karl Barth, which had convinced me earlier. I have called Barth's position a christological eschatology because he carried eschatology into Christology: In Christ's death and resurrection salvation has already been 'finished' (John 19:30). So the future of Christ will bring only the universal unveiling of the salvation of the world which has already been 'finished' or completed in Christ. (p. 37)

I have presented my own Christology 'in messianic dimensions' and over against Barth have maintained an eschatological Christology, according to which the beginning of the coming consummation of salvation has already taken place in the coming of Christ, and with Christ the eschatological future has already begun. That is to say, Christology is the beginning of eschatology: for in Christ 'all the promises of God are Yes and Amen' (2 Cor. 1:20). In contrast to Barth's time-eternity eschatology, I took up his initial 'forward eschatology', which he pursued in the spirit of Christoph Blumhardt and took it further. A Christology in 'messianic dimensions' must be followed by messianic ethics. By 'messianic' I mean in this connection a present already gripped and determined by the eschatological future. Eschatological future becomes present without ceasing to be future. In this way it makes of the present a present future. (pp. 37, 38)

If we understand eschatologically the life and teaching of Jesus, his self-surrender to death on the cross and his raising from the dead, we discover in his Sermon on the Mount a messianic interpretation of the Torah, and in the death and resurrection of Jesus we see the kingdom of God taking form in the world. (p. 38)

Kingdom of God ethics is discipleship-ethics, and the ethics of the discipleship of Jesus is the anticipation-ethics of his future. (p. 38) 
... an eschatologically open Christology opens our eyes to perceive the subsequent outpouring of the Spirit, and the experiences of the vital powers of the divine Spirit, as being 'powers of the world to come' (Heb. 6:5). The coming of the Holy Spirit is nothing other than the beginning of Christ's parousia. That is why the Spirit is called 'the pledge (or guarantee) of glory' (2 Cor. 1:22; Eph. 1:14). What begins here in the Spirit will be completed there in the kingdom of glory ... which is the consummation of all human history and the whole open creation ... It has its beginning in the coming of Christ, is already heralded in the kingdom of the Spirit and in the Spirit lays hold of the present. (p. 38)

Through the raising and exaltation of Christ, God has identified himself with Christ and made him Lord of God's restoration of man and nature, of God's new world. In Christ the messianic future has already begun. The present is already in the grip of the Spirit. Following Christ through the ethics of discipleship, Messianic ethics therefore means that Christians 'work for a corresponding re-evaluation of this world's values, so they may be in conformity with the coming world of God' (Moltmann 2012:39). Messianic ethics 'incorporates the principle of an "alternative life"' (Moltmann 2012:41). It is important to take cognisance that Moltmann does not compromise the Church and Christianity with politics, nations or culture (cf. Moltmann 2012:40), and he also does not advise refraining from any contact with the world (cf. Moltmann 2012:39): 'In these dimensions Christian ethics is neither a conformist responsibility in the world nor a separatist flight from the world' (Moltmann 2012:40).

\section{Conclusion}

We make choices, and get caught up by our choices. We cannot escape the choices we have made. Our choices draw the picture of who we really are.

Thiselton indeed reminds us that for many theologians 'to understand being human depends on understanding the human in relation to God' (Thiselton 2007:179), and this view finds expression in Calvin, Schleiermacher, Barth, Pannenberg, Moltmann, Balthasar, Rahner, and many more. Tillich totally differs in his understanding of man (Thiselton 2007:177-185). 'In relation to God' essentially leads to a relationship with God through the encounter with his Son reaching out to man.

Sometimes we are haunted by the dire consequences of the choices we have made. Where does the necessity of taking responsibility, and the choices we have made, take us? Where does moral responsibility lead us, when going back on our tracks? The more important question should rather be: Where does the love from God lead us on the path of analogia relationis? Man is inescapably a relational being. Man is unavoidably ' mitsein' - always man with other human beings, and never able to sever the lifesaving ties to his Maker. Man is ever part of nature and God's creation as a whole, in need of interacting responsibly with his environment. The Christian church is committed to God's future in the Kingdom of Christ. The future of the Kingdom is securely in God's hands.
In a world powerless in the grip of the 'sickness unto death', the church more than ever has the apostolic mission to spread the Gospel of the new man in Jesus Christ today, alongside the church's relief work, but even more important than that. The sinner needs to be redeemed in and through Jesus Christ, the Lord and Saviour of the world. The world needs a Saviour, the one and only real Saviour of the World, the Son of God himself. Without his healing and redeeming work, man, the world, has no future.

\section{Acknowledgements}

This article represents a thorough reworked and expanded version of an article published in Theology and the Church in South Africa 3(2), 2011. The article now also elaborates on the following aspects: human destructiveness; human distinctiveness; creatio continua; a new beginning for humankind; 'messianic ethics' and 'eschatological Christology'. It argues that the logical consequences of human destructiveness opens up the possibility for a new beginning.

\section{Competing interests}

The author declares that he has no financial or personal relationship(s) that may have inappropriately influenced him in writing this article.

\section{References}

Aristotle, 1975, The Politics, transl. T.A. Sinclair, Harmondsworth, Middlesex.

Augustine, 2003, Confessions, transl. A.C. Outler, and revised and updated by T. Gill, Bridge-Logos, Florida. PMCid:154344

Barth, K., 1957, The word of God and the word of man, transl. D. Horton, Harper \& Brothers Publishers, New York.

Barth, K., 1963, Church dogmatics, vol. 1 \& 2, transl. G.T. Thomson \& H Knight, G.W. Bromiley \& T.F. Torrance (eds.), T \& T Clark, Edinburgh.

Barth, K., 2000, Church dogmatics, vol. IV, 2, transl. G.W. Bromiley, G.W. Bromiley \& T.F. Torrance (eds.), T \& T Clark, Edinburgh.

Barth, K., 2004, Church dogmatics, vol. III, 2, transl. H. Knight, G.W Bromiley, J.K.S Reid \& R.H. Fuller, G.W. Bromiley \& T.F. Torrance (eds.) , T \& T Clark International, London/New York.

Barth, K., 2008, Church dogmatics, vol. I, 1, transl. G.W. Bromiley, G.W. Bromiley \& T.F. Torrance (eds.), T \& T Clark International, London/New York.

BBC News Europe, 2013, Swiss referendum backs executive pay curbs, 03 March 2013, viewed n.d., from http://www.bbc.co.uk/news/world-europe-21647937

Bochenski, I.M., 1966, Contemporary European philosophy, University of California Press, Berkeley/Los Angeles.

Calvin, J., 1964, Institutes of the Christian religion, vol. I, transl. H. Beveridge, William B. Eerdmans Publishing Company, Grand Rapids.

Dalberg, J.E.E., 1970, 'Letter in Life of Mandell Creighton', in B. Darwin (ed.), Oxford dictionary of quotations, Oxford University Press, London, p. 1.

Drobner, H.R., 2007, The fathers of the church - A comprehensive introduction, transl. S.S. Schatzmann, Hendrickson Publishers, Peabody.

Foucault, M., 2002, The order of things - an archaeology of the human sciences, transl. Tavistock/Routledge, Routledge Classics, London/New York.

Heidegger, M., 1935, Sein und Zeit, Max Niemeyer Verlag, Halle.

Heidegger, M., 1973, Brief over het Humanisme, transl. G.H. Buijssen, Lannoo, Utrecht.

Irenaeus, 2010a, 'Against Heresies (Book II)', in A. Roberts, J. Donaldson \& A. Cleveland Coxe (eds.), Saint Irenaeus of Lyons - Against Heresies, pp. 139-274, Ex Fontibus Co., n.p.

Irenaeus, 2010b, 'Against Heresies (Book V)', in A. Roberts, J. Donaldson \& A Cleveland Coxe (eds.), Saint Irenaeus of Lyons - Against Heresies, pp. pp. 553-655, Ex Fontibus Co., n.p.

Kierkegaard, S.A., 1974, Dagboeknotities, transl. W.R. Scholtens, Uitgeverij Ten Have N.V., Baarn.

Labuschagne, J.P., 1987, 'Die historiese konteks van 20ste Eeuse samelewingsteologieë', vol. 1 \& 2, DD proefskrif, Universiteit van Pretoria.

Lohse, B., 1985, A short history of Christian doctrine, transl. F.E. Stoeffler, FortressPress, Philadelphia. 
Macquarrie, J., 1975, Christian unity and Christian diversity, SCM Press, London. Macquarrie, J., 2003, Jesus Christ in modern thought, SCM Press, London.

Moltmann, J., 1999, God for a secular society - the public relevance of theology, SCM Press, London.

Moltmann, J., 2010, Sun of righteousness, ARISE! God's future for humanity and the earth, transl. M. Kohl, Fortress Press, Minneapolis.

Moltmann, J., 2012, Ethics of hope, transl. M. Kohl, Fortress Press, Minneapolis.

Ortega, Y. Gasset, J., 1958, De opstand der horden, transl. J Brouwer, HP Leopolds Uitgeversmij N.V., Gravenhage.

Pannenberg, W., 1976, The apostles' creed - In the light of today's questions, transl. M. Kohl, SCM Press, London.

Pannenberg, W., 1977, Faith and reality, transl. J. Maxwell, Search Press, London.

Pannenberg, W., 1999, Anthropology in theological perspective, transl. M.J. O'Connell, T \& T Clark, Edinburgh.
Price, D.J., 2002, Karl Barth's anthropology in the light of modern thought, William B. Eerdmans Publishing Company, Cambridge, UK.

Rousseau, J.J., 1963, 'A discourse on the origin of inequality', in J.J. Rousseau (ed.) The social contract and discourses, transl. G.D.H. Cole, pp. 143-229, Everyman's Library, New York.

Sartre, J-P., 1977, Being and nothingness, transl. H.E. Barnes, Methuen \& Co Ltd, London.

Scott, N.A., 1978, Mirrors of man in existentialism, Collins, London.

Tertullian, 2007, 'On the Resurrection of the flesh', in A. Roberts, J. Donaldson \& A Cleveland Coxe (eds.), The Ante-Nicene Fathers, vol. III, pp. 545-596, Cosimo Classics, New York.

Thiselton, A.C., 2007, The hermeneutics of doctrine, William B. Eerdmans, Grand Rapids. PMCid:2441648

Tillich, P., 1974, The courage to be, Collins, London.

Van Huyssteen, W.J., 2006, Alone in the world? Human uniqueness in science and theology, William B. Eerdmans Publishing Company, Grand Rapids/Cambridge, UK. PMid:16645122 